\title{
KAJIAN KRIMINOLOGIS KENAKALAN ANAK DALAM FENOMENA BALAPAN LIAR DI WILAYAH HUKUM POLRES BULELENG
}

Oleh :

\author{
Ni Putu Rai Yuliartini ${ }^{1}$
}

\begin{abstract}
Illegal race is one manifestation of juvenile delinquency, and if not dealt with quick and appropriately respons it will be a big problem. The illegal race is a "prohibited activity" and it is rule by Article 297 jo. Article 115letter b Law No. 22 of 2009 about Road Traffic and Road Transportation. In fact, in Singaraja there are many violations of these rules. Therefore, from the perspective of criminology needs to be known about the factors that cause child doing the wild race and mitigation efforts from the police.

This research is a law studies with the empirical aspec, which is primary data and secondary data as a source. Processing and data analysis was done by qualitatively. Overall results of the analysis of these data are presented descriptively, and fully explained about the problem that studied and also accompanied by a critical review.

Based on Containment theory proposed by Walter C. Reckless and research results, it can be seen that the factors that cause the child or juvenile do the illegal race, which is divided into 2 ( two ) that are inner and outer containment. Furthermore, It is described about the reduction of the illegal races by Buleleng Police, which is based on the results of research, there are 2 (two) reduction, that are by penal and non- penal facilities.
\end{abstract}

Keywords : Criminological, Delinquency, IllegalRace.

1 Mahasiswa Magister Ilmu Hukum Universitas Udayana, Alamat : SIngaraja-Bali, e-mail : - 


\section{PENDAHULUAN}

\section{Latar Balakang Masalah}

Kendaraan bermotor sebagai salah satu hasil dari kemajuan teknologimenjadi suatu kebutuhan dari sebagaian besar orang sebagai sebagai sarana transportasi dan tentunya berguna untuk menunjang mobilitas dan aktivitas seseorang. Menurut Arif Budiarto dan Mahmudah bahwa transportasi adalah pergerakan manusia, barang dan informasi dari suatu tempat ke tempat lain dengan nyaman, aman, murah, cepat dan sesuai dengan lingkungan untuk memenuhi kebutuhan hidup manusia. ${ }^{2}$

Salah satu sarana transportasi yang sering digunakan adalah sepeda motor. Pengguna sepeda motor dalam mengemudikan atau menggunakan kendaraan bermotor di jalan raya tentunya harus dilengkapi dengan segala surat-surat dan syarat-syarat teknis yang berhubungan dengan persyaratan dalam berlalu lintas di jalan raya. Akan tetapi dewasa ini seringkali ditemui kasus-kasus pelanggaran dalam berlalu lintas oleh anak, salah satunya adalah melakukan balapan liar di jalan raya ataupun berkendara tanpa memiliki SIM. Perbuatan yang melanggar norma-norma ataupun hukum positif inilah yang sering kita kenal dengan isitilah kenakalan anak.Kenakalan anak ini tidak hanya merupakan perbuatan yang melanggar

\footnotetext{
${ }^{2}$ Arif Budiarto dan Mahmudah, 2007, Rekayasa Lalu Lintas, UNS Press, Surakarta, h.1.
}

aturan atau hukum positif yang berlaku, tetapi juga melanggar norma-norma yang ada dalam masyarakat. ${ }^{3}$

Kenakalan anak ini diambil dari istilah asing yaitu Juvenile Delinquency yang berarti perilaku jahat (dursila) atau kejahatan/ kenakalan anak-anak muda, merupakan gejala sakit (patologis) secara sosial pada anak-anak dan remaja yang disebabkan oleh satu bentuk pengabaian sosial, sehingga mereka itu mengembangkan bentuk tingkah laku yang menyimpang. ${ }^{4}$

Fenomena balapan liar sebagai salah satu wujud kenakalan anak, akan menjadi masalah besar apabila tidak ditangani secara cepat dan tepat. Balapan liar ini merupakan perbuatan yang dilarang dan diatur dalam hukum positif yang berlaku di Indonesia. Hal ini diatur dalam Pasal 297 jo Pasal 115 huruf b Undang-Undang Nomor 22 Tahun 2009 tentang Lalu Lintas dan Angkutan Jalan, yang menyatakan bahwa : setiap orang yang mengemudikan Kendaraan Bermotor berbalapan di Jalan sebagaimana dimaksud dalam Pasal 115 huruf b dipidana kurungan palaing lama 1 (satu) tahun atau denda paling banyak Rp. 3.000.000,00 (tiga juta rupiah).

${ }^{3}$ Rachmad Iswan Nusi, 2014, Efektifitas Penanggulangan Terhadap Pelaku Balapan Liar Oleh Remaja (Studi di Polresta Samarinda), available at htttp:// hukum.ub.ac.id/wpcontent/uploads/2014/ 01/JURNAL-RACHMADISWAN.pdf, accessed 25 Mei 2014

${ }^{4}$ Kartini Kartono, 2011, Patologi Sosial 2 Kenakalan Remaja, PT. Raja Grafindo Persada, Jakarta, h. 6. 
Kenakalan anak seperti ini banyak kita jumpai di kota-kota besar dan bahkan sudah mulai menjamur di kota-kota kecil yang ada di setiap provinsi. Adapun tempat penulis melakukan penelitian ini adalah di Kota Singaraja yang merupakan bagian dari Wilayah Hukum Polres Buleleng. Balapan liar yang banyak terjadi di daerah Singaraja merupakan salah satu alternatif bagi anakanak remaja untuk mengekspresikan dirinya sebagai suatu pencitraan diri. Biasanya para pembalap liar ini membentuk suatu kelompok (komunitas) sebagai wadah mereka mengaktualisasikan diri dan sering menamakan kelompok mereka dengan sebutan geng motor. Balapan liar ini, menimbulkan ketakutan dan kekhawatiran di masyarakat. Karena resiko yang dihadapi sangat besar, mulai dari berurusan dengan polisi, kecelakaan yang mengakibatkan cacat hingga kematian.

Berdasarkan Pasal 297 jo Pasal 115 huruf b Undang-Undang Nomor 22 Tahun 2009 tentang Lalu Lintas dan Angkutan Jalan, sudah sangat jelas dinyatakan dalam pasal tersebut mengenai larangan adanya balapan liar. Namun pada kenyataan dan fakta yang ada, di Singaraja masih terdapat banyak pelanggaran terhadap aturan tersebut. Sehingga diperlukan upaya yang maksimal untuk menanggulangi balapan liar tersebut.

Peran Polres Buleleng seharusnya sangat mendominasi dalam upaya penanggulangan balapan liar di Kota Singaraja, selain itu diperlukan juga peran serta masyarakat sebagai pendukungnya. Melalui sarana penal maupun non penal, pihak Polres Buleleng dapat bertindak dengan cepat dan tepat dalam menanggulangi balapan liar yang sejatinya merupakan suatu bentuk tindakan yang melanggar hukum materiil mengenai lalu lintas.

Berdasarkan kondisi empirik demikian, penulis melihat adanya kesenjangan antara teori dengan praktek. Undang-undang Lalu Lintas dan Angkutan Jalan telah mengatur secara jelas bahwa balapan liar merupakan suatu tindak pidana yang berupa pelanggaran lalu lintas dan dapat dipidana. Tetapi dalam kenyataannya di masyarakat khususnya kalangan anak muda, balapan liar tersebut tetap saja terjadi. Melihat kondisi inilah, maka penulis tertarik untuk menganalisa lebih dalam mengenai faktor penyebab dan upaya penanggulangan balapan liar di wilayah hukum Polres Buleleng. Selanjutnya penulis memberikan judul dalam penelitian ini yaitu "Kajian Kriminologis Kenakalan Anak dalam Fenomena Balapan Liar di Wilayah Hukum Polres Buleleng”.

\section{Rumusan Masalah}

Berdasarkan uraian latar belakang masalah sebagaimana yang sudah dipaparkan diatas, maka dapat dirumuskan beberapa masalah sebagai berikut. 
a. Apakahyang menjadi faktor-faktor penyebab anak melakukan balapan liar di Singaraja?

b. Bagaimana upaya yang dilakukan oleh Kepolisian dalam penanggulangan balapan liar di Singaraja?

\section{Tujuan Penelitian}

Untuk mengetahui faktor-faktor yang menyebabkan anak melakukan balapan liar di Kota Singaraja serta untuk mengetahui upaya yang dilakukan kepolisian dalam menaggulangi balapan liar di Kota Singaraja.

\section{METODE PENELITIAN}

Metode penelitian yang digunakan dalam penulisan karya ilmiah ini adalah penelitian hukum dalam kajian empiris, dengan memandang hukum sebagai kenyataan yang mencakup kenyataan sosial, kenyataan kultur dan lain-lain (mengkaji law in action). ${ }^{5}$ Penelitian ini bersifat deskriptif yang bertujuan untuk melukiskan tentang sesuatu hal di daerah tertentu dan pada saat tertentu. ${ }^{6}$ Sehingga dalam penelitian ini yang dipergunakan adalah data primer dan data sekunder, yang pengumpulan datanya menggunakan teknik wawancara, studi dokumen dan observasi.

${ }^{5}$ Ahcmad Ali dan Wiwie Heryani, 2012, Menjelajahi Kajian Empiris terhadap Hukum, Kencana Prenada Media Group, Jakarta, h.2.

${ }^{6}$ Bambang Waluyo, 2008, Penelitian Hukum dalam Praktek, Sinar Grafika, Jakarta, h.8.

\section{HASIL DAN PEMBAHASAN}

\section{Faktor-faktor Penyebab Anak}

\section{Melakukan Balapan Liar di Singaraja}

Kenakalan anaktidak mengenal lapisan sosial dimana anak itu berada, baik dari kalangan orang kaya, miskin, keluarga berpendidikan atau tidak, kenakalan itu pastinya menjadi bagian yang tidak terpisahkan dari si anak. Sekarang yang menjadi persoalan adalah bagaimana caranya meminimalisir kenakalan tersebut, karena bentuk kenakalan yang dilakukan berbedabeda oleh setiap anak.

Menurut Kartini Kartono, wujud atau bentuk prilaku delinkuen atau nakal salah satunya adalah kebut-kebutan atau balapan liar di jalanan yang mengganggu keamanan lalu lintas dan membahayakan jiwa sendiri serta orang lain. ${ }^{7}$ Balapan liar ini semakin marak terjadi, tidak mengenal tempat baik di kota besar maupun di kota kecil. Salah satunya adalah yang terjadi di Kota Singaraja. Pada saat balapan liar berlangsung terdapat kepanitiaan kecil di dalamnya, yang setiap anggotanya itu memiliki tugas masingmasing. Adapun tugas-tugas itu antara lain: melakukan negosiasi, menjadi joki, mekanik, juri start, juru finish, pengawas, pemeriksa lintasan, bandar. ${ }^{8}$ Balapan ini terjadi karena

\footnotetext{
${ }^{7}$ Kartini Kartono, op.cit., h.21.

${ }^{8}$ Erdian Wirajaya dan Johris G. Purba, 2009, Balapan Liar: Ajang Sebuah Pergaulan, Prestasi atau Hanya Ugal-ugalan di Jalan, Usu E-Journal Kerabat Vol 1 No.1, available at
} 
terdapat beberapa faktor yang menyebabkan anak remaja melakukan balapan liar, walaupun mereka mungkin mengetahui bahwa perbuatan yang dilakukan itu dilarang atau bertentangan dengan aturan yang berlaku.

Untuk lebih memperjelas mengenai kajian tentang balapan liar sebagai wujud kenakalan anak, maka kita perlu mengetahui mengenai faktor-faktor penyebab anak melakukan suatu perbuatan yang menyimpang dari aturan (kenakalan anak). Dengan kata lain, kita harus mengetahui motivasi si anak melakukan suatu kenakalan. Motivasi merupakan usaha-usaha yang menyebabkan seseorang atau kelompok tertentu tergerak untuk melakukan suatu perbuatan karena ingin mencapai tujuan yang dikehendakinya atau mendapat kepuasan dengan perbuatannya. ${ }^{9}$

Penyebab kenakalan anak sangatlah kompleks. Semua pihak ikut berkontribusi terhadap munculnya kenakalan anak, baik secara aktif maupun secara pasif. Menurut Dr. Hassan Syamsi Basya, berbagai kajian mutakhir menunjukkan bahwa kenakalan anak sebagian besar disebabkan penderitaan dan perlakuan buruk yang mereka alami pada

http://repository.usu.

ac.id/handle/123456789/15423, accessed 9 Juli 2013

${ }^{9}$ Wagiati Soetodjo, 2010, Hukum Pidana Anak, Refika Aditama, Bandung, h. 16-17 masa kecil. ${ }^{10}$

Berdasarkan hasil penelitian di lapangan, terdapat lima faktor penyebab anak melakukan balapan liar di Kota Singaraja yaitu faktor karena hobi, karena faktor taruhan (judi), faktor lingkungan, faktor keluarga dan faktor pengaruh teknologi. Faktor-faktor tersebut kemudian dianalisa dengan teori yang dikemukakan pertama kalinya oleh Walter C. Reckless pada tahun 1961. Teori yang dimaksud adalah Containment Theory. Dalam teori ini dikemukakan bahwa terdapat beberapa cara pertahanan bagi individu agar bertingkah selaras dengan nilai dan norma-norma yang hidup dan berlaku dalam masyarakat. Pertahanan diri itu dalam teori ini ada 2 (dua) macam yaitu :

a. Inner containment, yaitu pertahanan yang berasal dari dalam (intern) yakni berupa kemampuan seseorang melawan atau menahan nafsu / godaan untuk melakukan kejahatan serta memelihara kepatuhankepatuhan terhadap norma-norma yang berlaku.

b. Outer containment, yaitu pertahanan yang berasal dari luar (extern) yakni suatu susunan hebat yang terdiri dari tuntutantuntutan legal dan larangan-larangan yang menjaga anggota masyarakat agar tetap

\footnotetext{
${ }^{10}$ Hassan Syamsi Basya, 2011, Mendidik Anak Zaman Kita; Cara Nabi dan Psikolog Muslim Mengantar Anak Jadi Lebih Cerdas, Lebih Shalih, Zaman, Jakarta, h. 122-123.
} 
berada dalam ikatan tingkah laku yang diharapkan oleh masyarakat tersebut. ${ }^{11}$

Dengan demikian, penulis selanjutnya akan mengklasifikasikan kelima faktor penyebab anak melakukan balapan liar di Kota Singaraja tersebut ke dalam Inner Containment dan Outer Containment berikut dengan uraian analisisnya.

\section{1) Inner Containment}

Dari kelima faktor penyebab anak melakukan balapan liar di Kota Singaraja sebagaimana disebutkan diatas, faktor penyebab yang termasuk ke dalam Inner Containment adalah "faktor hobi". Hal ini dikarenakan faktor hobi merupakan "faktor internal" yang bersumber dari dalam diri anak itu sendiri.

Dikaji dari segi pertahanan ataupun kontrol dari dalam diri anak tersebut (inner) dapat dilihat pada kurangnya kontrol diri dan internalisasi norma-norma sosial dari individu pelaku. Ketika anak tersebut tidak dapat mengontrol apa yang menjadi keinginan yang ada dalam diri mereka untuk melakukan kegiatan balapan liar, maka dengan kata lain anak tersebut tidak mampu melawan dorongan untuk melakukan penyimpangan norma dan kemudian memutuskan untuk melakukan penyimpangan norma (pelanggaran) untuk memenuhi keinginan

\footnotetext{
${ }^{11}$ Koentjoro, Kriminologi dalam Perspektif Psikologi Sosial, available at : http://koentjoropsy.staff.ugm.ac.id/wp-

content/uploads/Kriminologi-1.pdf, accessed 12 April 2014
}

berbalapan liar sebagai bentuk penyaluran hobinya dengan mengabaikan norma-norma yang berlaku di masyarakat.

\section{2) Outer Containment}

Dari kelima faktor penyebab anak melakukan balapan liar di Kota Singaraja, faktor penyebab yang termasuk ke dalam Outer Containment yakni:

1. Faktor Lingkungan

Lingkungan menyediakan wadah bagi seorang anak untuk menjadi pribadi yang unggul dan berkualitas ataupun sebaliknya. Melihat pada faktor lingkungan sebagai outer containment mayoritas, maka anak yang berada pada lingkungan pergaulan yang tidak baik, dalam arti bergaul dengan temantemannya yang melakukan perilaku menyimpang, maka akan mudah mengikuti perbuatan yang menyimpang.

Begitu pula dengan balapan liar, jika seorang anak bergaul dengan anakanak/remaja lain yang melakukan balapan liar, maka anak tersebut berpotensi besar menyerap faktor kriminogen yang diberikan oleh teman-temannya.Artinya anak tersebut berada pada lingkungan pergaulan yang tidak memiliki pertahanan terhadap kepatuhan dan norma-norma yang berlaku.

2. Faktor Taruhan (judi)

Berdasarkan kondisi normatif yang ada di negara kita ini, taruhan atau judi adalah perbuatan yang dilarang oleh hukum positif yang berlaku di negara ini. Walaupun sudah 
jelas diatur, tetap saja masih banyak pelanggaran yang dilakukan. Salah satunya adalah melakukan taruhan atau judi pada balapan liar.

Pada aksi balapan liar yang terjadi di Kota Singaraja, biasanya terdapat sejumlah taruhan berupa uang yang disepakati oleh pihak-pihak yang bertanding. Mengenai nilai uang taruhan biasanya berkisar mulai dari ratusan ribu rupiah hingga jutaan rupiah. Melihat faktor taruhan (judi) sebagai salah satu outer containment dalam balapan liar, maka taruhan tersebut merupakan perilaku menyimpang lain yang mendukung balapan liar tersebut. Potensi pelaku balapan liar melakukan taruhan akan terwujud manakala ada pelaku balapan liar lain yang sepakat memenuhi taruhan tersebut. Oleh karena itu, terjadinya taruhan dalam balapan liar disebabkan adanya persamaan tujuan untuk memperoleh keuntungan finansial dari balapan liar melalui kesepakatan taruhan antar pelaku.

\section{Faktor Teknologi}

Teknologi memiliki pengaruh yang cukup besar terhadap perilaku anak di zaman sekarang ini. Perkembangan teknologi ternyata tidak selamanya memberikan dampak yang positif. Dewasa ini penggunaan sepeda motor sudah sering disalahgunakan terutama di kalangan anak muda. Mereka menggunakan sepeda motor sebagai salah satu sarana untuk berbalapan, antara individu satu dengan individu lainnya, ataupun antara satu komunitas dengan komunitas lainnya.

Faktor teknologi sebagai salah satu outer containment dalam aksi balapan liar merupakan dampak dari modernisasi.Dampak negatif yang ditimbulkan oleh perkembangan teknologi memacu para pelaku balapan liar untuk memperoleh sarana prasarana berbalapan liar dijalan raya sehingga melanggar batasan-batasan yang ada dalam norma-norma yang berlaku khususnya peraturan berlalu-lintas.

4. Faktor Keluarga

Keluarga merupakan tempat berinteraksi antar anggota keluarga, yakni antara suami dengan istrinya, antara orang tua dengan anaknya, anak dengan saudaranya serta dengan anggota keluarga lainnya yang tinggal dalam satu rumah. Interaksi tersebut dilakukan sesuai dengan etika keluarga yang ditentukan atau dicontohkan oleh orang tua (ayah dan ibu), sehingga bila interaksi tersebut dilakukan dengan baik maka akan tercipta hubungan yang harmonis antara sesama anggota keluarga.

Faktor keluarga sebagai outer containment dalam balapan liar menjadi faktor yang strategis namun sering terabaikan. Dampak negatif dari faktor-faktor eksternal lain tidak akan mudah mempengaruhi anak apabila sejak dini anak tersebut telah dibekali pertahanan atau kontrol diri yang kuat dari orang tuanya. Kontrol dari keluarga akan 
mendukung anak untuk mempertahankan diri dari perbuatan yang melanggar norma. Kelemahan pertahanan dari keluarga akan memudahkan faktor-faktor kriminogen dari luar keluarga menembus nilai dan norma ada. Keempat faktor diatas merupakan "faktor eksternal" yang berasal dari luar diri pelaku yang menyebabkan anak melakukan balapan liar. Dari segi outer, norma dan aturan dalam masyarakat menjadi faktor penting untuk mengkaji permasalahan balapan liar. Banyaknya aksi balapan liar yang dilakukan oleh anak yang belum cukup umur dapat memberiasumsi bahwa nilai-nilai moral dan ketaatan terhadap hukum positif tentang lalu lintas yang berlaku dalam masyarakat sudah mulai berkurang.

Anak yang melakukan balapan liar tidak memiliki pertahanan yang kuat secara eksternal untuk melindungi dan membatasi anak dari serangan dan tekanan dari luar diri anak untuk melakukan pelanggaran. Ketika faktor-faktor eksternal tidak dapat memberikan pertahanan yang kuat kepada seorang anak, maka anak tersebut akan dengan mudah melangkahi kepatuhankepatuhan dan norma-norma yang ada. Seharusnya faktor-faktor eksternal yang ada disekitar anak bekerjasama menjadi sarana pertahanan atau kontrol bagi anak untuk mematuhi norma. Kontrol dan perhatian dari orang tua serta kaum pendidik terhadap anak menjadi rawan.Anak dapat belajar untuk melakukan berbagai hal bak itu positif maupun negatif, bisa berasal dari pergaulannya sehari-hari, bisa melalui televisi atau media sosial.Sehingga keberhasilan anak dalam memfilter perbuatan yang benar dan melanggar sangat dipengaruhi oleh kuat lemahnya kontrol atau pertahanan dari faktorfaktor eksternal.

\section{Upaya Penanggulangan Balapan Liar di Singaraja}

Kenakalan anak yang terjadi saat ini khususnya dalam hal balapan liar di jalan raya, merupakan salah satu bentuk penyimpangan yang selalu melekat pada kehidupan masyarakat. Terhadap masalah ini, tentunya telah banyak usaha penanggulangan yang dilakukan, mengingat dampak yang dihasilkan dari perilaku menyimpang ini cukup membuat resah kehidupan masyarakat.

Upaya penanggulangan kejahatan sesungguhnya merupakan upaya terus menerus dan berkesinambungan yang selalu ada, bahkan tidak akan pernah ada upaya yang bersifat final. Upaya itu dilakukan untuk menjamin perlindungan dan kesejahteraan masyarakat. ${ }^{12}$ Maka dari itu digunakanlah hukum sebagai suatu komponen sistem sosial yang dianggap lebih efektif menyelesaikan

\footnotetext{
${ }^{12}$ Budi Suhariyanto, 2012, Tindak Pidana Teknologi Informasi (Cybercrime) Urgensi Pengaturan dan Celah Hukumnya, PT. Raja Grafindo Persada, Jakarta, h. 22.
} 
problem sosial yang berupa kejahatan di masayarakat. ${ }^{13}$

Hukum yang merupakan suatu sistem, dapat berjalan dengan efektif dan dipercaya oleh masyarakat, jika dalam pelaksanaannya sesuai dengan perasaan dan nilai-nilai yang tumbuh berkembang dalam masyarakat. Oleh karena itu, diperlukan strategi untuk memformulasikan hukum atau undangundang yang dalam hal ini dikenal dengan politik hukum pidana atau sering disebut politik kriminal.

Politik kriminal (criminal policy) adalah usaha rasional untuk menanggulangi kejahatan. Politik kriminal ini merupakan bagian dari politik penegakan hukum dalam arti luas (law enforcement policy). Semuanya merupakan bagian dari politik sosial (social policy), yakni usaha dari masyarakat atau negara untuk meningkatkan kesejahteraan warganya. ${ }^{14}$ Sehingga dapat dikatakan bahwa upaya penanggulangan kejahatan atau pelanggaran perlu ditempuh dengan pendekatan kebijakan, dalam arti:

a. Ada keterpaduan (integralitas) antara politik kriminal dan politik sosial;

b. Ada keterpaduan (integralitas) antara upaya penanggulangan kejahatan dengan "penal" dan "nonpenal". 15

\footnotetext{
${ }^{13}$ Ibid, h. 23 .

${ }^{14}$ Muladi dan Barda Nawawi, 2010, Bunga Rampai Hukum Pidana, PT Alumni, Bandung, h.1.

${ }^{15}$ Barda Nawawi Arief, 2008, Bunga Rampai Kebijakan Hukum Pidana (Perkembangan
}

Peran yang dilakukan kepolisian sebagai pihak yang paling bertanggung jawab dalam memberantas aksi balap motor liar seolah-olah tak ada habisnya. Dalam upaya mencegah terjadinya balap motor liar, pihak kepolisian sudah mengupayakan berbagai cara, dimulai dari metode paling lunak hingga metode yang keras. Tetapi upaya tersebut belum membuahkan hasil yang nyata. ${ }^{16}$

Demikian halnya dalam penanggulangan balapan liar di kota Singaraja yang dilakukan oleh Polres Buleleng harus dilakukan dengan penuh tanggung jawab dan ada keterpaduan antara sarana "penal" (hukum pidana) dan sarana "non-penal" (di luar hukum pidana), sehingga nantinya balapan liar yang ada dapat segera ditanggulangi.

1) Upaya Penanggulangan Balapan Liar di

Kota Singaraja oleh Polres Buleleng $\underline{\text { melalui Sarana Penal }}$

Penanggulangan balapan liar di Kota Singaraja oleh Polres Buleleng melalui sarana penal merupakan salah satu fungsionalisasi dari kebijakan hukum pidana (penal policy)khususnya pada tahap aplikasi (kebijakan yudikatif) yang dilakukan oleh aparat penegak hukum salah satunya kepolisian. Upaya penanggulangan balapan

Penyusunan Konsep KUHP Baru), Kencana, Jakarta, h. 3-4.

${ }^{16}$ Dyah Ayu Widyastuti, 2013, BALAP MOTOR LIAR: Studi Deskriptif mengenai Pelabelan dan Tindakan Sosial Polisi, Journal Universitas Airlangga: Komunitas Vol 2 No. 1, available at

http://journal.unair.ac.id/article_4654_media135_ca tegory135.html, diakses 12 April 2014 
liardi Kota Singaraja melalui sarana penal lebih menitikberatkan pada sifat represif sesudah balapan liar terjadi yang merupakan upaya penindakan dan penegakan hukum terhadap pelaku balapan liar sesuai dengan peraturanperundang-undangan yang berlaku.

Dalam lingkup kebijakan di bidang hukum pidana materiil, balapan liar merupakan salah satu perbuatan yang dilarang dan diancam pidana berdasarkan Undangundang Lalu Lintas dan Angkutan Jalan dalam Bab IX Lalu Lintas, pada Bagian Keempat Tata Cara Berlalu Lintas, pada Paragraf 5 Kecepatan, pada Pasal 115 huruf b yang menyatakan "Pengemudi Kendaraan Bermotor dilarang berbalapan dengan Kendaraan Bermotor Lain.”

Ketentuan pidana terhadap larangan balapan liar terdapat dalamBab XX Ketentuan Pidana pada Pasal 297 yang mengatur "Setiap orang yang mengemudikan Kendaraan Bermotor berbalapan di Jalan sebagaimana dimaksud dalam Pasal 115 huruf $\mathrm{b}$ dipidana dengan pidana kurungan paling lama 1 (satu) tahun atau denda paling banyak Rp3.000.000,00 (tiga juta rupiah). "Sehingga balapan liar merupakan salah satu bentuk tindak pidana lalu lintas berupa pelanggaran, sebagaimana disebutkan dalam Pasal 316 ayat (1) bahwa ketentuan sebagaimana dimaksud dalam Pasal 297 adalah pelanggaran.
Selanjutnya, upaya penanggulangan balapan liar di Kota Singaraja melalui sarana penal yang dilakukan oleh Polres Buleleng merupakan kebijakan hukum pidana dalam lingkup kebijakan di bidang hukum pidana formal (hukum acara pidana) dalam artian upaya penerapan dan penegakan hukum pidana materil. Berdasarkan hasil penelitian penulis,upaya penanggula-ngan balapan liar di Kota Singaraja melalui sarana penal yang dilakukan oleh Polres Buleleng, yakni sebagai berikut:

a) Melakukan penindakan pelanggaran terhadap pelaku balapan liar.

Penyelenggaraan upaya penanggulangan balapan liar melalui sarana penal didasarkan atas Rencana Operasi (RENOPS) Zebra Polres Buleleng yang ada pada setiap tahun, dalam rangka penegakan hukum dalam berlalu lintas dengan mengedepankan kegiatan penegakan hukum berupa penindakan terhadap pelanggaran lalu lintas. Salah satu tujuan operasi ini adalah mencegah terjadinya balap liar atau trek-trekan, khususnya anak menjadi salah satu sasaran operasi sebagai pengendara di bawah umur dan tidak memiliki SIM.

Dalam prakteknya, ketika balapan liar dilakukan oleh anak, maka Satuan Tugas Penegakan Hukum Subsatgas Penindakan Pelanggaran Lalu Lintas akan melakukan penindakan pelanggaran terhadap pelaku. Penindakan pelanggaran diawali dengan 
melakukan penangkapan pelaku untuk dibawa ke Kantor Polres Buleleng beserta barang bukti berupa sepeda motor yang digunakan pelaku berbalapan di jalan. Setelah itu, polisi akan melakukan pemeriksaan lebih lanjut terhadap pelaku dan sepeda motornya. Pada umumnya, pelaku balapan liar tidak hanya melanggar Pasal 115 huruf b Undangundang Lalu Lintas dan Angkutan Jalan, dimana saat proses pemeriksaan polisi menemukan bentuk pelanggaran lain yang turut dilakukan pelaku saat melakukan balapan liar, antara lain: pelaku tidak memiliki Surat Izin Mengemudi saat berbalapan di jalan menurut Pasal 281 Undang-undang Lalu Lintas dan Angkutan Jalan dan/atau sepeda motor yang digunakan pelaku tidak memenuhi persyaratan teknis dan laik jalanyang diaturdalam Pasal 285 Undang-undang Lalu Lintas dan Angkutan Jalan.

Merujuk pada fakta tersebut, maka polisi selanjutnya memberikan Surat Tilang kepada pelaku karena telah melakukan beberapa bentuk pelanggaran lalu lintas selain balapan liar itu sendiri. Surat Tilang tersebut kurang lebih berisi tentang identitas pelaku dan jenis pelanggaran lalu lintas yang dilakukan sekaligus ketentuan hukumnya, serta waktu sidang di Pengadilan Negeri Singaraja. Setelah surat tilang diberikan kepada pelaku, maka pihak Polres Buleleng melakukan penyitaan sepeda motor yang digunakan pelaku berbalapan sebagai barang bukti. Kemudian, pihak kepolisian akan melakukan pemanggilan terhadap orang tua pelaku sebelum hari sidang.

b) Melimpahkan berita acara pemeriksaan cepat ke Pengadilan Negeri Singaraja

Setelah proses penindakan pelanggaran dilakukan, maka pihak Polres Buleleng melimpahkan berita acara pemeriksaan cepat ke Pengadilan Negeri Singaraja.

c) Menyerahkan kembali barang bukti sitaan (sepeda motor) kepada pelaku

Barang bukti berupa sepeda motor yang dikendarai pelaku untuk berbalapan akan dikembalikan kepada pelaku setelah pelaku melaksanakan putusan Pengadilan Negeri Singaraja, yang umumnya dijatuhi pidana denda. Sepeda motor tersebut diambil di Unit Satlantas Polres Buleleng dengan menyerahkan bukti pembayaran denda.

2) Upaya Penanggulangan Balapan Liar di Kota Singaraja oleh Polres Buleleng $\underline{\text { melalui Sarana Non Penal }}$

Upaya penanggulangan balapan liardi Kota Singaraja melalui sarana non penal lebih menitikberatkan pada sifat pencegahan sebelum balapan liar itu terjadi. Berdasarkan penelitian penulis, upaya penanggulangan balapan liar di Kota Singaraja melalui sarana non-penal yang dilakukan oleh Polres Buleleng terdiri atas upaya preemtif dan upaya preventif. Penyelenggaraan upaya preemtif dan preventif tersebut didasarkan 
atas Rencana Operasi (RENOPS) Patuh dan Simpatik Polres Buleleng. RENOPS PatuhPolres Buleleng dilaksanakan dalam rangka meningkatkan kesadaran dan kepatuhan masyarakat dibidang Kamseltibcar Lantas (keamanan, keselamatan, ketertiban dan kelancaran lalu lintas). RENOPSSimpatik Polres Buleleng dilaksanakan dalam rangka membangun opini dan kepercayaan masyarakat terhadap Polri, guna meningkatkan kesadaran dan kepatuhan hukum di bidang Kamseltibcar Lantas. RENOPS Patuh dan Simpatik Polres Buleleng dilaksanakan dengan mengedepankan kegiatan preemtif melalui pendidikan dan penyuluhan lalu lintas,dan tindakan preventif melalui pengaturan, penjagaan, pengawalan dan patroli lalu lintas untuk mencegah terjadinya kegiatan yang mengganggu Kaseltibcar Lantas salah satunya adalah balapan liar.

\section{Upaya Preemtif}

Upaya preemtif merupakan tugas dari Satuan Tugas Preemtif Polres Buleleng, yang terbagi atas Subsatgas Deteksidan Subsatgas Dikmas.Kegiatan preemtif yang dilakukan oleh Polres Buleleng untuk mencegah sejak dini terjadinya balapan liar yakni melaksanakan kegiatan pendidikan lalu lintas meliputi pembinaan potensi masyarakat, penerangan dan penyuluhan lalu lintas, sebagai upaya meningkatkan kesadaran dan disiplin berlalu lintas bagi pengguna jalan dengan melakukan kegiatan antara lain: Polisi Sahabat Anak;Patroli Keamanan Sekolah; Police Goes to Campus/School; Pramuka Saka Bhayangkara Krida Lantas; Cara Aman Sekolah danKawasan Tertib Lalu Lintas; Kemitraan Sekolah; Safety Riding dan Safety Driving; Taman Lalu Lintas; Kampanye keselamatan lalu lintas; Sekolah mengemudi; Forum Lalu lintas dan Angkutan Jalan.

\section{Upaya Preventif}

Upaya preventif merupakan tugas dari Satuan Tugas Preventif, yang terbagi atas Subsatgas Pengaturan dan Penjagaan, dan Subsatgas Patroli dan Pengawalan. Kegiatan preventif yang dilakukan untuk mencegah terjadinya balapan liar yakni melaksanakan kegiatan pencegahan meliputi penjagaan, pengaturan, pengawalan dan patroli lalu lintas di lokasi rawan balapan liar di Kota Singaraja yang berpotensi menimbulkan kecelakaan, pelanggaran dan kemacetan lalu lintas sebagai upaya memberikan rasa aman dan nyaman bagi pengguna jalan dengan melakukan kegiatan antara lain:

(a) Pengaturan lalu lintas selain di tempat dan persimpangan yang rutin dilaksanakan, juga di tempat lain yang memerlukan kehadiran petugas Polri, terutama di tempat-tempat yang berpotensi menjadi lokasi balapan liar di Kota Singaraja;

(b) Penjagaan lalu lintas selain di pos tetap juga di pos sementara yang memerlukan 
penjagaan petugas Polri untuk memantau aktivitas anak-anak/para pelajar yang berkumpul di pinggir jalan sebagai pelaku potensial balapan liar;

(c) Melaksanakan patroli lalu lintas baik menggunakan roda 2 maupun roda 4 minimal dilakukan oleh 2 (dua) orang petugas di beberapa tempat tertentu yang dilansir atau dicurigai sebagai lokasi balapan liar, terutama saat malam hari menjelang dini hari;

(d) Meminta kepada masyarakat agar segera melaporkan kegiatan balapan liar kepada pihak kepolisian, terutama masyarakat sekitar lokasi rawan balapan liar yang merasa tergangguakibat adanya balapan liar;

(e) Mencari informasi adanya balapan liar di lokasi tertentu dari babinkamtibmas dan polisi yang berpakaian preman;

(f) Memberikan hadiah kepada masyarakat sipil yang memberikan informasi adanya balapan liar, sehingga masyarakat sipil lebih termotivasi dalam berperan serta mencegah balapan liar.

\section{SIMPULAN DAN SARAN}

\section{Simpulan}

Berdasarkan hasil penelitian yang telah dipaparkan dalam bab-bab sebelumnya, maka dapat disimpulkan bahwa :
1) Faktor-faktor yang menyebabkan anak melakukan balapan liar di Kota Singaraja, antara lain :

a. Inner Containment

Faktor penyebab yang termasuk ke dalam Inner Containment adalah "faktor hobi". Ketika anak tersebut tidak bisa mengontrol apa yang menjadi keinginan yang ada dalam diri mereka untuk melakukan kegiatan balapan liar, maka dengan kata lain anak tersebut tidak mampu melawan dorongan untuk melakukan penyimpangan norma.

b. Outer Containment

Faktor penyebab yang termasuk ke dalam Outer Containment adalah faktor lingkungan, faktor taruhan, faktor teknologi, dan faktor keluarga. Norma dan aturan dalam masyarakat menjadi faktor penting untuk mengkaji permasalahan balapan liar. Banyaknya aksi balapan liar ini dapat memberikan kita asumsi bahwa nilainilai moral dan ketaatan terhadap aturan lalu lintas yang berlaku dalam masyarakat sudah mulai berkurang. Sehingga dapat dikatakan bahwa anak yang melakukan balapan liar tidak memiliki pertahanan yang kuat secara eksternal untuk melindungi dan membatasi anak dari serangan dan 
tekanan dari luar diri anak untuk melakukan suatu pelanggaran.

2) Upaya penanggulangan balapan liar di Kota Singaraja oleh Polres Buleleng dapat dibedakan menjadi 2 yaitu :

a. Sarana Penal

Penanggulangan balapan liar di Kota Singaraja oleh Polres Buleleng melalui sarana penal yang lebih menitikberatkan pada sifat represif sesudah balapan liar terjadi yang merupakan upaya penindakan dan penegakan hukum terhadap pelaku balapan liar sesuai dengan peraturan perundang-undangan yang berlaku.

b. Sarana Non Penal

Upaya penanggulangan balapan liar di Kota Singaraja melalui sarana non penal lebih menitikberatkan pada sifat pencegahan sebelum balapan liar itu terjadi, yaitu melalui upaya preemtif dan upaya preventif. Upaya ini dilaksanakan dengan mengedepankan kegiatan preemtif melalui pendidikan dan penyuluhan lalu lintas, dan tindakan preventif melalui pengaturan, penjagaan, pengawalan dan patroli lalu lintassalah satunya untuk mencegah terjadinya kegiatan balapan liar.

\section{Saran}

1) Keluarga dalam hal ini orang tua, lebih memberikan kesem-patan kepada anak untuk lebih mengekspresikan perilakunya tanpa mengabaikan kontrol yang baik kepada anaknya, sehingga kenakalan anak dapat dikurangi dan masih dalam tahap yang wajar.

2) Dalam upaya menanggulangi balapan liar di kota Singaraja, diharapkan Polres Buleleng lebih memaksimalkan penerapan sanksi pidana melalui sarana penalnya, agar dapat menimbulkan efek jera bagi pelaku-pelaku balapan liar dan anak lain yang ingin melakukan percobaan balapan liar ini dapat mengurungkan niatnya karena takut akan ancaman pidana yang diberikan jika mereka tertangkap telah melakukan balapan liar.

\section{DAFTAR PUSTAKA}

Ali, Ahcmad dan Heryani, Wiwie, 2012, Menjelajahi Kajian Empiris terhadap Hukum, Kencana Prenada Media Group, Jakarta

Arief, Barda Nawawi, 2008, Bunga Rampai Kebijakan Hukum Pidana (Perkembangan Penyusunan Konsep KUHP Baru), Kencana, Jakarta

Basya, Hassan Syamsi, 2011, Mendidik Anak Zaman Kita; Cara Nabi dan Psikolog Muslim Mengantar Anak Jadi Lebih Cerdas, Lebih Shalih, Zaman, Jakarta

Budiarto, Arif dan Mahmudah, 2007, Rekayasa Lalu Lintas, UNS Press, Surakarta 
Kartono, Kartini, 2011, Patologi Sosial 2 Kenakalan Remaja, PT. Raja Grafindo Persada, Jakarta

Muladi dan Barda Nawawi, 2010, Bunga Rampai Hukum Pidana, PT Alumni, Bandung

Waluyo, Bambang, 2008, Penelitian Hukum dalam Praktek, Sinar Grafika, Jakarta

Soetodjo, Wagiati, 2010, Hukum Pidana Anak, Refika Aditama, Bandung

Suhariyanto, Budi, 2012, Tindak Pidana Teknologi Informasi (Cybercrime) Urgensi Pengaturan dan Celah Hukumnya, PT. Raja Grafindo Persada, Jakarta

Dyah Ayu Widyastuti, 2013, BALAP MOTOR LIAR: Studi Deskriptif mengenai Pelabelan dan Tindakan Sosial Polisi, Journal Universitas Airlangga: Komunitas Vol 2 No. 1, available at

http://journal.unair.ac.id/article_4654_me dia135_category135.html, diakses 12 April 2014

Erdian Wirajaya dan Johris G. Purba, 2009, Balapan Liar : Ajang Sebuah Pergaulan,
Prestasi atau Hanya Ugal-ugalan di Jalan, Usu E-Journal Kerabat Vol 1 No. 1 , available at http://repository.usu.ac.id/handle/123456 $\underline{789 / 15423}$, accessed 9 Juli 2013

Koentjoro, Kriminologi dalam Perspektif Psikologi Sosial, available at : http://koentjoro-psy.staff.ugm.ac.id/wpcontent/uploads/Kriminologi-1.pdf, accessed 12 April 2014

Rachmad Iswan Nusi, 2014, Efektifitas Penanggulangan Terhadap Pelaku Balapan Liar Oleh Remaja (Studi di Polresta Samarinda), available at htttp://hukum.ub.ac.id/wpcontent/uploads/2014/01/JURNAL-

RACHMAD-ISWAN.pdf, accessed 25 Mei 2014

Undang-Undang Republik Indonesia Nomor 22 Tahun 2009 Tentang Lalu Lintas dan Angkutan Jalan. Lembaran Negara Republik Indonesia Tahun 2009 Nomor 96 dan Tambahan Lembaran Negara Republik Indonesia Nomor 5025 
Vol.7 No.3 2014 